2 Escudier E. Escudier B. Henry-Amar M. e' al. Effects of infused intralipids on neutrophil chemotaxis during total parenteral nutrition. J Parent Ent Nutr 1986; 10: 596-8.

3 Palmblad J. Brostrom O, Lahnborg G, et al. Neutrophil functions during total parenteral nutrition and intralipid infusion. Am J Clin Nutr 1982: 35: 1430-6.

\section{Lymphocytic gastritis: a newly described entity}

SIR, - Haot et al in the discussion of their recent paper (Gut 1988; 29: 1258-64) state that in connection with varioliform gastritis, chronic erosive gastritis, chronic verrucous gastritis 'some well known pathology textbooks do not even mention it' and give reference to Morson and Dawson's book' and my own on mucosal biopsy. ' I would ask Haot et al to turn to page 81 of that text for a description of that very same condition in as much detail as was current in 1984 when the manuscript went to the publishers.

$R$ WHITEHEAD

Department of Pathology,

Flinders Medical Centre,

Bedford Park,

South Australia 5042

\section{References}

1 Morson BC, Dawson MP. Gastrointestinal pathology. Oxford: Blackwell, 1979.

2 Whitchead R. Mucosal biopsy of the gastrointestinal tract. Philadelphia: Saunders, 1985.

\section{Cytomegalovirus associated gastroduodenal ulceration}

SIR, - The case report by Spiller et al rightly draws attention to the need to bear CMV in mind as a potential pathogen in cases of gastrointestinal ulceration.

Certain points, exemplified by a case previously reported by us, ${ }^{2}$ are worthy of re-emphasis. Although the patient reported by Spiller and colleagues developed only superficial ulceration and made a good recovery, the more usual at risk patient in CMV associated gastrointestinal ulcerative disease (organ transplant patients, ${ }^{2}$ patients with AIDS $^{3}$ or with other causes of immune compromise ${ }^{4}$ ) are likely to develop deeper ulcers with the attendant risk of serious haemorrhage and/or perforation. The patient we described died from massive upper gastrointestinal haemorrhage from a CMV-associated duodenal ulcer, refractory to medical and surgical management, 50 days after a heart transplant. An important feature of this case was the deep seated nature of the tissue damage and its vasculitic features, which impaired healing of the attempted surgical procedure (oversewing), leading to renewed - and fatal-haemorrhage.

Gastrointestinal ulceration, haemorrhage and per- foration thus joins the protean potential manifestations of CMV infection, ${ }^{+}$with the suggestion that immune-competent subjects tolerate, contain and repair the mucosal damage more effectively than immunodeficient patients.

NIGEI, H BRAMWEIII

Department of Pathology, McMaster Universitv. 1200 Main Street West,

Hamilton, Ontario,

Canada L8N $3 Z 5$

\section{References}

1 Spiller RC, Lovell D. Silk DBA. Adult acquired cytomegalovirus infection with gastric and duodenal ulceration. Gut 1988: 29: 1109-11.

2 Bramwell NH. Davies RA. Koshal A, et al. Fatal gastrointestinal hemorrhage caused by cytomegalovirus duodenitis and ulceration after heart transplantation. $J$ Heart Transplant 1987: 6: 303-6. (Abstracted in The vear book of surgery (Schwartz SI et al, eds). Chicago: Year Book Medical Publishers, 1988: 147-8.)

3 Frank D, Raicht RF. Intestinal perforation associated with cytomegalovirus infection in patients with acquired immune deficiency syndrome. Am J (jastroenterol 1984: 79: $201-5$.

4 Lamberson HV, Jr. Cytomegalovirus (CMV): the agent. its pathogenesis, and its epidemiology. Prog Clin Biol Res 1985; 182: 149-73.

\section{Books}

Classic papers in viral hepatitis. Edited by Christine L Lee and Howard C Thomas. (Pp. 295; not illustrated; £42.50.) Cambridge: Cambridge Medical Books, 1988.

This is one of a series of books designed to provide 'a valuable collection of classic(al) and historical papers that report ideas and work that has had an impact on knowledge'. Viral hepatitis, which is caused by at least five different viruses, is a major public health problem throughout the world. An enormous literature has accumulated on the subject since its discovery in Australia in 1965-1968. This volume is an authology from many thousands of publications.

The translation by Professor G Giangrande of the University of London of the description of hepatitis by Hippocrates is an important contribution, and there are many other gems in this volume. But of course with such a vast field it is impossible to give equal weighting to all aspects of viral hepatitis and its important complications, and it is inevitable that 